\title{
Negosiasi Tradisi Islam dan Tradisi Lokal dalam Perayaan Nadran di Desa Dadap, Kecamatan Juntinyuat, Kabupaten Indramayu
}

\author{
Isfiyatun \\ isfiyatun@gmail.com \\ Institut Agama Islam Negeri Syekh Nurjati Cirebon
}

\begin{abstract}
Abstrak: Penelitian ini membahas tentang Nadran, yakni upacara yang dilakukan oleh para nelayan dengan maksud mewujudkan rasa syukur para nelayan atas hasil tangkap laut. Nadran ini bertujuan sebagai suatu pengharapan masyarakat agar ditingkatkan kembali hasil tangkap laut di masa mendatang. Selain itu juga upacara nadran ini bertujuan untuk mengharapkan keselamatan atau tolak bala. Oleh sebab itu, upacara nadran dilakukan secara rutin. Dalam upacara ini terdapat pencampuran budaya. Hal ini terlihat dalam prosesi ritual upacara nadran yaitu dalam pembukaan upacara nadran masyarakat desa Dadap melakukan tahlilan, serta ditutup dengan melakukan manaqiban, kegiatan tersebut biasanya dilakukan oleh masyarakat yang menganut agama Islam. selain itu juga terdapat persembahan sesaji yang biasa dilakukan oleh masyarakat beragama Hindu. Dalam ritual agama Hindu, sesaji ini sebagai sesuatu penghormatan roh leluhur kepada penguasa laut. Tujuan penelitian ini adalah untuk mengidentifikasi bagaimana masyarakat Desa Dadap mengelola pertemuan budaya lokal dan agama Islam. Pendekatan dalam penelitian ini adalah kualitatif dengan menggunakan metode etnografi. Kesimpulanny adalah, bahwa sebab terjadinya perbedaan kepercayaan masyarakat Dadap mengenai perayaan nadran yaitu di latar belakangi oleh pemahaman terhadap agama Islam yang berbeda.
\end{abstract}

Kata Kunci: Negosiasi, Islam, Budaya Lokal, Perayaan Nadran.

\section{A. PENDAHULUAN}

Tradisi masyarakat Indonesia dipengaruhi oleh kepercayaan animisme, yaitu kepercayaan bahwa benda-benda memiliki roh. Masyarakat Indonesia juga percaya bahwa roh-roh tersebut dapat menolong dan menyembuhkannya dari penyakit, penderitaan, kematian dan segala marabahaya. Agama Hindu mulai diperkenalkan sekitar abad pertama dan kedua Masehi oleh para pedagang India melalui jalur pantai Indonesia. Kontak perdagangan yang dilakukan oleh kedua belah pihak mengakibatkan masuknya agama Hindu kedalam kultur masyarakat Indonesia.agama Budha diperkenalkan oleh para pendeta Budha dari India sekitar abad keenam Masehi dengan cara melakukan hubungan resmi ke Istana raja-raja Indonesia. Para pendeta ini membawa misi yang lebih populer yaitu dengan mengenalkan ajaran Sidarta Gautama dan hukum-hukumnya. Dalam waktu yang begitu singkat pengaruh agama Hindu dan Budha telah berhasil memberikan corak kerajaan-kerajaan Indonesia. 
Islam masuk ke Indonesia bersentuhan dengan keyakinan, kultur, dan budaya lokal. Hal ini mengakibatkan corak Islam di Indonesia menjadi khas dan unik. Islam datang ke Indonesia begitu luwes dan damai dengan menyerap dan mengakomodasi berbagai keyakinan dan budaya lokal, namun tidak menghindarkan nilai-nilai ajaran Islam. ${ }^{1}$ Salah satu contoh yaitu proses Islamisasi yang dilakukan oleh Wali songo di tanah Jawa.

Proses Islamisasi di Jawa dilanjutkan oleh Wali Songo. Para Wali Songo memiliki masing-masing tugas dalam menyebarkan Islam keseluruh pelosok Jawa melalui tiga wilayah yaitu wilayah pertama adalah Surabaya, Gresik, dan Lamongan di Jawa Timur. Wilayah kedua yaitu Demak, Kudus dan Muria di Jawa Tengah. Wilayah ketiga yaitu Cirebon di Jawa Barat. Dalam berdakwah, para Wali Songo menggunakan jalur-jalur tradisi yang sudah dikenal oleh masyarakat Indonesia kuno. Para Wali Songo melekatkan nilai-nilai Islam pada praktik dan kebiasaan tradisi setempat. ${ }^{2}$ Dengan demikian Islam mengalami akulturasi dengan budaya lokal.

Diantara Wali Songo tersebut yang paling terkenal dengan keseniannya yaitu Sunan Kalijaga. Dalam menyebarkan Islam Sunan Kalijaga sangat pandai memanfaatkan budaya dan praktik keagamaan lokal yaitu dengan menggunakan media pewayangan dan gamelan. Sebagian besar cerita dalam pewayangan ini bersumber pada tradisi Hindu yang kemudian secara kreatif Sunan Kalijaga menyisipkan ajaran Islam di dalam seperti halnya Mahabhrata dan Ramayana. ${ }^{3}$ Dengan demikian bisa dikatakan bahwa Islam menyesuaikan diri dengan budaya lokal yang sudah lama tertanam pada masyarakat.

Dari berbagai pembahasan diatas yang bersentuhan dengan adanya suatu pertemuan antara budaya lokal dan Agama-agama yang masuk ke Indonesia sangat berpengaruh terhadap beberapa budaya lokal yang berada di Nusantara ini. Dari berbagai budaya lokal yang ada di Indonesia salah satunya yaitu Nadran.

Nadran merupakan salah satu upacara budaya yang berada di Indonesia. Nadran biasanya dilakukan oleh masyarakat pesisir pantai yang berprofesi sebagai nelayan. Oleh karena itu nadran sering disebut sebagai pesta laut atau upacara yang

\footnotetext{
${ }^{1}$ Kementrian Pendidikan dan Kebudayaan, Indonesia dalam Arus Sejarah 3:Kedatangan dan Peradaban Islam, (PT. Ichtiar Baru Van Hoeve Kerjasama dengan Kementrian Pendidikan dan Kebudayaan Republik Indonesia)Hlm: 128-129

${ }^{2}$ Ajid Thohir, Studi Kawasan Dunia Islam, Op. Cit, hlm: 397

${ }^{3}$ Kementrian Pendidikan dan Kebudayaan, Indonesia dalam Arus Sejarah 3:Kedatangan dan Peradaban Islam,Op. Cit, hlm: 128
} 
dilakukan oleh para nelayan dengan maksud untuk mewujudkan rasa syukur para nelayan lewat hasil tangkap laut. Kata nadran itu sendiri berasal dari bahasa Arab yaitu nadzar yang artinya pemenuhan janji. Dengan demikian nadran bisa diartikan sebagai pemenuhan janji para nelayan sebagai serwujudan rasa syukur seorang hamba Tuhan dari hasil tangkap laut yang melimpah. ${ }^{4}$

Nadran bertujuan sebagai rasa syukur atas hasil laut serta berharap agar ditingkatkan kembali hasil tangkap laut dimasa mendatang. Dengan ini dimaksudkan agar upacara nadran diselenggarakan secara rutin oleh para nelayan disetiap tahunnya. Upacara nadran ini biasanya diselenggarakan setiap tahun sekali.

Berbicara mengenai nadran, masyarakat desa Dadap atau sering disebut sebagai Wong Dadap biasanya memanfaatkan hasil alam Laut atau mayoritas bermata pencaharian sebagai nelayan. Para nelayan di desa Dadap biasanya mewujudkan rasa syukur atas hasil lautnya dengan menyelenggarakan upacara nadran. Di desa Dadap sendiri, upacara nadran dilaksakan antara bulan Januari sampai Maret. Upacara nadran ini bukan hanya dimaksudkan untuk mewujudkan rasa syukur para nelayan atas hasil tangkap lautnya akan tetapi juga mengharapkan keselamatan atau wong dadap menyebutnya sebagai tolak bala.

Dalam upacara nadran terdapat pencampuran beberapa budaya. Hal ini dibuktikan dalam upacara nadran yaitu melakukan tahlilan, manaqiban yang biasa dilakukan oleh masyarakat penganut agama Islam. Tahlilan dimaksudkan sebagai pembuka dalam upacara nadran, agar upacara nadran berjalan dengan lancar dan manaqiban dilakukan pada penutupan acara, agar mendapat berkah. Selain itu dalam nadran juga terdapat persembahan sesajen yang berisi bunga tujuh rupa, buah-buahan, replika perahu, kepala kerbau. Sesajen dalam ritual agama Hindu adalah sebagai suatu penghormatan roh leluhur kepada penguasa laut agar diberi limpahan hasil laut. Upacara nadran di Desa Dadap dilaksanakan dengan rutin karena sudah turun temurun. ${ }^{5}$

Sehubungan mengenai upacara nadran, masyarakat Dadap memiliki kepercayaan yang berbeda-beda. Ada yang menganggap bawa upacara nadran merupakan hal sangat penting. Karena menurutnya upacara nadran ini dilakukan secara turun temurun jika tidak dilakukan maka akan terjadi sesuatu yang tidak

\footnotetext{
${ }^{4}$ Wawancara bersama ust. Robah, Pkl. 23:13, kamis, 12 Nopember 2015, bertempat di Posko PPL

${ }^{5}$ Wawancara bersama ust. Robah, Op. Cit.
} 
diinginkan. Ada juga yang mengganggap bahwa upacara nadran merupakan suatu yang menyimpang, Hal ini dikarenakan bahwa upacara nadran mengandung unsurunsur kemusyrikan karena banyak sekali masyarakat yang menganggap nadran sebagai pembawa berkah. ${ }^{6}$ Walaupun demikian masyarakat desa Dadap tetap melaksanakan upacara nadran tanpa ada yang merasa menyimpang dari ajaran agama.

\section{B. METODOLOGI}

Dalam penelitian ini penulis menggunakan penelitian Kualitatif dengan pendekatan etnografi. Etnografi sendiri di definisikan secara umum yaitu pengamatan berperan serta sebagai bagian dari penelitian lapangan. ${ }^{7}$ Teknik pengumpulan data pada penelitian ini dilakukan dengan cara wawancara secara mendalam. Wawancara ini bertujuan untuk mencari informasi yang terkait dengan negosiasi tradisi lokal dan tradisi Islam dalam perayaan Nadran. Selanjutnya adalah observasi yang bertujuan untuk mengamati secara langsung perayaan nadran di desa Dadap, dimana negosiasi tradisi lokal dan tradisi Islam berlangsung dalam lingkup perayaan nadran dan yang selanjutnya adalah teknik adalah dokumentasi.

\section{HASIL DAN PEMBAHASAN}

Geertz pun memberikan sumbangsi dalam mendefinikan agama yaitu sebagai suatu sistem budaya. ${ }^{8}$ Sedangkan kebudayaan merupakan suatu pengorganisasi pengertian-pengertian yang tersimpul dalam simbol-simbol yang berkaitan dengan eksistensi manusia. $^{9}$

\section{Agama di Desa Dadap}

Menurut Geertz, agama memiliki tiga bagian yaitu sistem pengetahuan atau sistem makna, sistem nilai dan sistem simbol.

${ }^{6}$ Wawancara bersama ust. Robah, Ibid

${ }^{7}$ Lexy J. Moleong, metode penelitian Kualitatif, Ibid, hlm: 26

${ }^{8}$ Clifford Geertz, The Religion of Java, diterjm: Aswab Mahasin, Abangan, Santri, Priyai Dalam Masyarakat Jawa, (Jakarta: Pustaka Jaya, 1989), hlm: x. Dalam sumber lain juga mengatakan pandangan Geertz meengenai agama, menurutnya agama merupakan sistem simbol yang berfungsi untuk menanamkan motivasi dan semangat yang kuat serta mendalam dan juga bertahan lama pada manusia dengan menciptakan konsepsi-konsepsi yang bersifat umum mengenai eksistensi, dan membungkus konsepsi tersebut dengan sedemikian rupa dalam suasana nyata, sehingga suasana dan motivasi itu kelihatan sangat realitas. Lihat bunya Roger M. Keesing, CULTURAL ANTHROPOGY: A Contemporary Perpective, Second Edition,diterjemh: R. G. Soekadijo, Antropoli Budaya: Suatu Perspektif Kontemporer, edisi kedua, Hlm: 94

${ }^{9}$ Clifford Geertz, The Religion of Java, Ibid, hlm: x 


\section{a. Sistem Pengetahuan Atau Sistem Makna}

Sistem pengetahuan atau sistem makna disebut juga sistem kognitif yaitu representasi dari model of atau model tentang (model ini merepresentasikan kenyataan yang ada atau yang sudah ada). Berkaitan dengan pandangan Geertz diatas, di desa Dadap terdapat upacara keagamaan yang sudah dilakukan masyarakat Dadap secara turun-temurun, upacara tersebut dilakukan dengan begitu rutin dalam setahun sekali. Upacara tersebut juga masih bertahan sampai sekarang, masyarakat Dadap menyebutnya sebagai upacara nadran. Dengan demikian, Upacara nadran yang dilakukan masyarakat Dadap ini dalam bahasa Geertz disebut sebagai sistem kognitif atau representasi dari model of. Karena masyarakat desa Dadap melakukan upacara ini sebagai wujud atau tindakan untuk menghormati nenek moyang. oleh sebab itu, wujud atau tindakan secara nyata ini disebut model of.

\section{b. Sistem Nilai}

sistem nilai atau juga disebut sistem evaluatif yaitu sebuah bentuk representasi dari model for atau model untuk (sistem ini tidak merepresentasikan suatu kenyataan yang sudah ada, melainkan suatu kenyataan yang masih harus dibentuk atau diwujudkan). ${ }^{10}$ Jika model of sebagai wujud nyata dari sebuah tindakan, maka model for ialah suatu pedoman untuk melakukan tindakan atau bisa juga dikatan sebagai suatu pengetahuan manusia yang secara selektif digunakan untuk mendorong dan menciptakan suatu tindakan. Di Desa Dadap, masyarakat mempercayai bahwa nadran harus dilakukan karena jika tidak lakukan maka dikhawatirkan akan terjadi sesuatu yang tidak diinginkan, oleh sebab itu nadran juga disebut sebagai tolak bala. Masyarakat Dadap juga meyakini bahwa nadran merupakan suatu penghormatan atau rasa syukur kepada Allah Yang Maha Kuasa karena telah memberikan hasil tangkap laut yang begitu melimpah.

${ }^{10}$ Geertz, After The Fact: Two Countries, Four Decade, One Anthropologist, diterjmh: Landung Simatupang, AFTER THE FACT Dua Negara, Empat Dasawarsa, Satu antropolog, (Yogyakarta: LkiS, 1995), hlm: XIV, lihat juga karyanya Nur Syam , Madzhab-Madzhab Antropologi, (Yogyakarta: LkiS, 2007), hlm: 91 
Dengan dilaksanakanya nadran maka masyarakat berharap agar dilimpahkan kembali hasil tangkap lautnya. Dengan demikian suatu pengetahuan masyarakat ini disebut oleh Geertz sebagai model for, karena dengan pengetahuan ini masyarakat Dadap menjadi terdorong dalam melaksanakan upacara nadran. Penjelasan tersebut dapat disimpulkan lebih sederhana yaitu upacara keagamaan yang dilakukan oleh masyarakat ini merupakan model of atau model tentang. Sedangkan ajaran yang diyakini kebenarannya sebagai dasar atau acuan melakukan upacara keagamaan ini merupakan model for atau model untuk.

\section{c. Sistem Simbol}

Suatu permasalahan teoritis muncul yaitu mengenai konsep diatas yaitu mengenai cara menghubungkan antara sistem kognitif dan sistem nilai, kaitan mengenai bagaimana menerjemahkan antara sistem kognitif menjadi sistem nilai atau menerjemahkan sistem nilai menjadi sistem kognitif, oleh sebab itu Geertz berpendapat sistem simbol, karena dengan simbol manusia memungkinkan dapat menangkap hubungan antara dunia nilai dengan dunia pengetahuan. Dengan demikian beliau mengambil inti dari agama yaitu terdiri dari tiga bagian diantaranya adalah sistem kognitif, sistem nilai dan sistem simbol yang memungkinkan pemaknaan atau interpretasi.

Mengenai sistem simbol, upacara nadran ini mengandung suatu penghormatan kepada nenek moyang atau leluhur. Dimana lambang penghormatan ini dapat dilihat dari berbagai rangkaian kegiatan upacara nadran seperti halnya persembahan sesaji atau sesajen dalam berbagai variasi seperti halnya berupa makanan, kepala kerbau, bunga tujuh rupa, dan biji-bijian.

Persembahan sesaji terdapat kepala kerbau yang merupakan inti dari upacara nadran, karena dalam upacara nadran terdapat pelarungan kepala kerbau. Melarungkan kepala kerbau bertujuan untuk membuang sial atau membuang segala kebodohan manusia. Dimana kerbau dilambangkan sebagai hewan yang penurut dan bodoh. Sedangkan laut dilambangkan sebagai ilmu, maka dengan tenggelamnya kepala kerbau ini ke tengah-tengah laut diharapkan akan menghilangkan segala kebodohan dan kesialan. Kerbau juga disebut sebagai hewan yang penurut, oleh sebab itu masyarakat Dadap diharapkan akan menuruti selaga perintah Tuhan. 
Masyarakat desa Dadap dalam menyiapkan sesajian harus melengkapi segala sesajian yang sudah ditentukan, karena jika semua tidak terkumpul maka dikhawatirkan suatu saat nanti penunggu atau penjaga laut akan menagih dan menimbulkan hal-hal yang tidak diinginkan.Jika sesajian ini belum terkumpul, maka acara ini tidak bisa untuk dilanjutkan. Masyarakat Dadap meyakini bahwa jika mereka tidak luput dari gangguan-gangguan yang tidak diinginkan, apabila sajen-sajen tidak dibuat dengan semestinya. Oleh karena itu dalam melaksanakan upacara nadran semua sesajen yang ditentukan harus terkumpul.

Upacara nadran tidak hanya mengandung pemberian sesajen kepada leluhur dengan bahan makanan yang telah disucikan melalui do'a saja, akan tetapi juga dengan tindakan menghormati seperti itu. Sebuah penghormatan ini diberikan oleh masyarakat desa Dadap dengan mempersembahkan sesajian tersebut ketengah-tengah laut. Penghormatan ini dipersembahkan untuk nabi Khidir yang dianggap sebagai penjaga Laut.

Penjelasan diatas dapat disimpulkan bahwa agama merupakan sistem lambang yang berfungsi sebagai penegak dari berbagai perasaan dan motivasi manusia yang kuat, yang berjangkauan luas dan abadi pada diri manusia itu sendiri dengan merumuskan berbagai konsep mengenai keteraturan umum eksistensi sehingga menyebabkan perasaan-perasaan dan motivasi-motivasi mereka secara unik dan realistik. ${ }^{11}$

\section{Agama dan Masyarakat Desa Dadap}

Berkaitan dengan Agama diatas, Geertz berpandangan demikian karena melihat masyarakat yang berada di Mojokuto, dimana Mojokuto ini merupakan kota kecil yang berada di bagian tengah Jawa. Kota ini juga sebagai pusat perdagangan, pendidikan dan juga pemerintahan. ${ }^{12}$ Sistem ekonomi kota ini digolongkan lima jenis mata pencaharian utama yang mewakili penduduk Jawa asli di Mojokuto yaitu petani, pedagang kecil, pekerja tangan yang bebas, buruh kasar dan pegawai, guru atau administratur. Demikian pula penggolongan menurut kepercayaan keagamaan, etnis dan ideologi politik menghasilkan tiga tipe utama kebudayaan yang menggambarkan organisasi moral kebudayaan Jawa yang berkenaan dengan tingkah laku petani, Buruh, pekerja tangan,

\footnotetext{
${ }^{11}$ Betty R. Scharf, The Sociological Study of Religion, ibid, hlm: 36

${ }^{12}$ Clifford Geertz, The Religion of Java, Ibid, hlm: 1
} 
pedagang dan pegawai. Tiga tipe kebudayaan ini adalah abangan, santri, dan priyai. $^{13}$

\section{a. Abangan}

Abangan merupakan salah satu kelompok sosial dari tiga sub-kebudayaan yang bicarakan oleh Geertz. Tiga sub-kebudayaan yang masing-masing merupakan struktur sosial yang berlainan ini terdapat di desa, pasar dan birokrasi pemerintahan. ${ }^{14}$ Tiga struktur kebudayaan yang berbeda ini tidak hanya dilatar belakangi oleh lingkungan yang berbeda, akan tetapi dibarengi juga dengan adanya sejarah kebudayaan yang berbeda yang berkaitan dengan masuknya agama serta peradaban Hindu dan Islam di Pulau Jawa. Oleh sebab itu tradisi keagamaan abangan lebih menitik beratkan pada aspek-aspek animisme yang terdiri dari pesta keupacaraan yang disebut sebagai slametan, kepercayaan ini begitu kompleks dan rumit terhadap makhluk halus, dan seluruh serangkaian teori dan praktek pengobatan, sihir, dan magi.

Masyarakat Desa Dadap merupakan masyarakat yang terbiasa tinggal di wilayah pesisir pantai. Oleh sebab itu, masyarakat desa Dadap mayoritas bermata pencaharian sebagai nelayan. Akan tetapi desa Dadap juga merupakan wilayah dataran dengan ketinggian 0,6 meter diatas permukaan laut yang terdiri dari persawahan serta pemukiman.Dengan demikian dilihat dari letak geografis diatas, bisa dikatakan bahwa mata pencaharian masyarakat Dadap, tidak hanya sebagai nelayan, tetapi juga ada yang bertani, buruh tani, berdagang ada juga PNS, POLRI atau TNI, pensiunan, Swasta, serta pelajar, dan mahasiswa.

Tradisi keagamaan yang berhubungan dengan upacara nadran ini memiliki peranan yang sangat penting, baik ritual atau seremonial, yaitu sebagai pengingat manusia yang berkenaan dengan eksistensi dan hubungan dengan lingungan. Dengan adanya upacara-upacara juga masyarakat tidak hanya mengingat, akan tetapi juga membiasakan menggunakan simbol-simbol yang bersifat abstrak yang berada pada tingkat pemikiran dari berbagai kegiatan sosial yang nyata dan berada dalam kehidupan sehari-hari. Hal ini terjadi karena upacara dilakukan secara rutin menurut skala waktu tertentu dan untuk peristiwa atau keperluan tertentu. ${ }^{15}$

${ }^{13}$ Clifford Geertz, The Religion of Java, Ibid, hlm: 5-6

${ }^{14}$ Clifford Geertz, The religion of Java, Ibid, hlm: 6

${ }^{15}$ Clifford Geertz, The religion of Java, Ibid, hlm: XI-XII 
Pada kegiatan upacara seperti slametan tersebut tidak hanya bermaksud sebagai persembahan atau penghormatan kepada roh-roh nenek moyang yang memiliki sifat magis, akan tetapi dalam kegiatan tersebut terdapat tujuan yang penting yaitu menciptakan keadaan yang sejahtera, aman dan bebas. ${ }^{16}$ Begitupun dalam upacara nadran, tidak hanya sebagai sarana hubungan manusia dengan Sang Pencipta saja, akan tetapi juga hubungan manusia dengan manusia. Nadran tidak hanya sebagai sarana untuk menyatukan hubungan manusia dengan manusia, akan tetapi juga hubungan manusia dengan Tuhan, selain itu juga pelaksanaan nadran merupakan salah satu cara untuk mempertahankan budaya leluhur atau lokal.

\section{b. Santri}

Masyarakat Desa Dadap sendiri terdapat perbedaan dalam melaksanakan upacara nadran. Hal ini sama seperti dalam upacara selametan yang dipaparkan Geertz, ada beragam pendapat mengenai upacara slametan pada masyarakat mojokuto. Pada masyarakat Desa Dadap yang mayoritas memeluk agama Islam pun ada berbagai pendapat mengenai nadran. Ada pro dan kontra mengenai upacara nadran. Pendapat yang pro terhadap upacara nadran ini beranggapan bahwa nadran merupakan hal yang sangat penting, sedangkan yang kontra beranggapan bahwa upacara nadran merupakan sesuatu yang mengandung halhal yang musyrik. Seperti yang diketahui pada bab sebelumnya bahwa masyarakat desa Dadap mayoritas memeluk agama Islam. Masyarakat Islam yang pro terhadap pelaksanaan upacara nadran ini disebut oleh Geertz sebagai abangan, sedangkan yang kontra disebut sebagai santri.

Geertz melihat hal itu pada ragam budaya masyarakat Islam di Mojokuto yang menunjukan adanya identitas yang berbeda yaitu Kelompok muslim santri yang tergolong begitu taat beribadah, ada juga kelompok abangan yang mengaku beragama Islam namun kurang taat pada ajaran agama, dan adapula kelompok lain yaitu muslim priyai yang pengalaman agamanya lebih ekslusif, kelompok ini terdiri dari orang-orang kaya dan ningrat. Namun kelompok yang ketiga ini tidak begitu terlihat di desa Dadap. Kelompok sosial yang kedua ini yaitu santri dalam melihat perayaan nadran merupakan sesuatu yang menyimpang dari syari'at.

\footnotetext{
${ }^{16}$ Ahmad Kholil, Agama Kultural Masyarakat Pinggiran, (Malang: UIN-Maliki Press, 2001), Hlm: 91
} 


\section{Negosiasi Agama dan Budaya dalam Praktik Nadran di Desa Dadap}

Negosiasi agama dan budaya dalam praktik nadran di Desa Dadap terjadi sudah lama, namun masih bisa dirasakan sampai sekarang. Negosiasi sendiri menurut KBBI adalah proses tawar menawar dengan jalan berunding atau bermusyawarah dengan tujuan untuk mencapai kesepakatan bersama anatara satu pihak dengan pihak yang lain. Negosiasi tradisi Islam dan tradisi lokal ini berakibat pada munculnya integrasi dan konflik di tengah-tengah masyarakat. Integrasi dan konflik ini merupakan proses dari negosiasi. Integrasi sendiri merupakan suatu proses penyesuaian diantara unsur-unsur yang berbeda dalam kehidupan bermasyarakat sehingga menghasilkan pola kehidupan masyarakat yang memiliki keserasian. Proses Integrasi juga terdapat asimilasi, akulturasi, dan inkulturasi.

\section{a. Konflik}

Keragaman tradisi umat Islam khususnya di Jawa ini memiliki pemahaman ajaran agama Islam yang begitu bervariasi. Oleh sebab itu timbul berbagai perbedaan dalam interpretasi dan pelaksanaan ajaran agama Islam. penyebaran agama Islam yang tidak merata juga tertanam kuat dalam struktur masyarakat lokal, hal ini menjadi faktor penting yang sangat mempengaruhi tingkat penerimaan dan pemahaman ajaran Islam yang berbeda-beda. Perbedaan tersebut terkadang menimbulkan konflik. Konflik ini berasal dari kesalah pahaman terhadap kelompok lain karena perbedaan teerhadap pemahaman.

Keragaman tradisi masyarakat Islam di Desa Dadap pun memiliki pemahaman yang berbeda. Hal ini dapat dilihat dari prosesi ritual dalam perayaan nadran. Dalam melakukan prosesi ritual nadran masyarakat desa Dadap memiliki kepercayaan yang berbeda. Ada masyarakat yang memiliki anggapan bawa upacara nadran merupakan hal sangat penting. Karena menurutnya upacara nadran ini dilakukan secara turun temurun jika tidak dilakukan maka akan terjadi sesuatu yang tidak diinginkan. Ada juga masyarakat yang mengganggap bahwa perayaan nadran merupakan suatu yang menyimpang, Hal ini dikarenakan bahwa upacara nadran mengandung unsur-unsur kemusyrikan karena banyak sekali masyarakat yang menganggap nadran sebagai pembawa berkah. ${ }^{17}$

\footnotetext{
${ }^{17}$ Wawancara bersama bapak ust. Robah, Ibid
} 
Dalam perayaan nadran terjadi konflik ideologi dalam konteks gagasan atau pemahaman yang berbeda antara masyarakat Islam yang pro dan kontra. Kelompok masyarakat Islam yang pro adalah mereka yang menerima dan mendukung akan terselenggaranya perayaan nadran. Sedangkan kelompok masyarakat Islam yang kontra adalah mereka yang berpendapat bahwa perayaan nadran merupakan hal yang menyimpang dari ajaran agama Islam. ${ }^{18}$

Dalam melaksanakan perayaan nadran ini terdapat ketegangan yang terjadi antara kelompok umat Islam yang menganut tradisi nadran dengan kelompok Islam yang kontra. Hal ini tidak jauh berbeda dengan dengan konflik ideologi yang dijelaskan oleh Geertz mengenai kelompok abangan, santri dan priyai di Mojokuto. Dimana beliau menjelaskan dalam bukunya yaitu konflik-konflik ideologi antara kelompok umat Islam dengan berupa ketegangan-ketegangan perasaan. Antara kelompok-kelompok saling menyindir, mengejek, menyerang dan bahkan menjatuhkan satu sama lain. Kelompok masyarakat Islam abangan menilai bahwa kaum santri merupakan orang yang hanya bersih lahirnya saja dengan penampilan yang memakai atribut Islam yaitu memakai sarung, kerudung, dan peci. Tetapi perilakunya tidak jauh berbeda dengan orang yang tidak bermoral. Pertentaangan ini diarahkan kepada moralitas kaum santri yang sering kali merasa lebih suci daripada kelompok-kelompok yang lainnya. Begitun sebaliknya, kaum santri menganggap bahwa kaum abangan sebagai penyembah berhala sedangkan priyai sebagai orang-orang yang sombong. ${ }^{19}$

Walaupun dalam perayaan nadran ini terdapat konflik ideologi, namun sama sekali tidak melahirkan ketegangan berupa perlawanan fisik seperti unjuk rasa ataupun demonstrasi. Berdasarkan penjelasan diatas perbedaan fahan atau pertentangan faham ini berakar pada persepsi dan penafsiran yang berbeda. Bagi para penganut perayaan nadran sebenarnya tidak memiliki ketegangan atau pertentangan perasaan apapun selama melakukan rangkaian acara dalam perayaan nadran.

Dalam perayaan nadran terjadi adanya interaksi Islam dan budaya lokal. Negosiasi tradisi Islam dan budaya local menimbulkan adanya perubahan dalam budaya lokal, sehingga masyarakat Desa Dadap dapat menerima adanya budaya

\footnotetext{
${ }^{18}$ Abdullah Ali, Tradisi Kliwonan Gunung Jati..... Op. Cit, hlm: 56

${ }^{19}$ Roland Robertson, Agama dalam Analisa dan Interpretasi Sosiologis, Op. Cit. Hlm: 209-
} 
local yaitu perayaan nadran. Budaya sebagaimana merupakan warisan nenek moyang yang harus dijaga dan agama Islam ikut mewarnai kehidupan manusia secara beriringan tanpa ada pertentangan. Hal ini bisa dikatakan bahwa umat Islam bisa melakukan kompromi dalam kegiatan tradisional, dimana dalam perayaan ini terjadi negosiasi tradisi Islam dan tradisi lokal dalam lingkup perayaan nadran sebagai peninggalan kebudayaan Jawa yang mengandung nilainilai Hindu-Budha dengan disisipkan nilai-nilai tradisi Islam seperti halnya tahlilan dan manaqiban.

\section{b. Integrasi}

\section{1) Asimilasi}

Asimilasi merupakan suatu proses peleburan ${ }^{20}$ atau pembauran dari dua kebudayaan yang disertai dengan hilangnya ciri khas kebudayaan asli sehingga membentuk kebudayaan baru. Dengan demikian ada suatu proses pembauran dari kebudayaan yang lama dengan kebudayaan yang yang datang dan memunculkan kebudayaan baru. Berbicara mengenai asimilasi, nadran merupakan salah satu tradisi lokal yang didalamnya terdapat percampuran budaya, seperti halnya mengandung nilai-nilai tradisi Hindu-Budha dan Islam. Hal ini bisa dilihat dalam ritual perayaan nadran di desa Dadap yang begitu kental dengan tradisi lokal. Perayaan Nadran yang sudah dipercaya oleh masyarakat akan membawa keberkahan. Dalam ritual perayaan Nadran, Tahlilan merupakan acara pembuka yang dimaksudkan agar dengan bacaan dzikir dan shalawat serta bertawasul kepada Nabi Khidir (diyakini sebagai penjaga laut), semua rangkaian kegiatan berikutnya dilancarkan. Walaupun acara inti dari nadran yaitu persembahan sesajen yang dalam agama Hindu sebagai penghormatan roh leluhur kepada penguasa laut agar diberi hasil laut yang melimpah. Namun nilai yang terkandung dalam persembahan sesajen disesuaikan dengan ajaran Islam yaitu sebagai rasa syukur para nelayan kepada Tuhan dan dari dilaksanakannya nadran diharapkan akan menghilangkan segalasesuatu yang tidak diinginkan atau tolak bala. ${ }^{21}$

Penjelasan diatas merupakan proses asimilasi, dimana dalam perayaan nadran yang begitu kental dengan budaya Hindu-Budha dengan berbagai makna yang terkandung didalamnya, sekarang melebur atau berbaur dalam

${ }^{20}$ Diambil dari KBBI offline by Ebta Setiawan, Email: Ebta Setiawan@ gmail.com

${ }^{21}$ Wawancara bersama bapak ust. Robah 
tradisi Islam, sehingga dalam hal ini nadran terlihat begitu berbeda. Nadran tidak hanya mengandung unsur-unsur Hindu-Budha akan tetapi nadran pun mengandung unsur-unsur agama Islam. Nadran yang ini dianggap oleh kaum santri sebagai sesuatu yang mengandung unsur-unsur kemusyrikan, namun untuk meredam hal tersebut maka masyarakat desa Dadap menyisipkan unsur-unsur Islam. Sehingga nadran ini bisa diselaraskan denga ajaran Islam.

\section{2) Akulturasi}

Akulturasi menurut Bekker yaitu pertemuan dua kebudayaan dan terdapat suatu penerimaan dari nilai-nilai kebudayaan lain, dengan ini nilai yang beru dipadukan kedalam kebudayaan yang lama. ${ }^{22}$ Dalam hal ini nadran merupakan percampuran budaya. Dimana didalamnya terdapat unsur-unsur budaya Hindu-Budha dan unsur-unsur budaya Islam. Hal ini terbukti didalam melakukan ritual perayaan nadran seperti adanya pembukaan dengan melakukan tahlil dan juga terdapat suatu persembahan yang biasa dilakukan oleh umat Hindu. Akulturasi ini merupakan salah satu usaha masyarakat desa Dadap dalam menguburkan perbedaan-perbedaan yang menimbulkan konflik antara yang pro terhadap nadran atau disebut sebagai abangan dengan masyarakat yang kontra terhadap adanya perayaan nadran atau disebut sebagai santri. Percampuran budaya Islam dan budaya lokal ini merupakan usaha masyarakat Desa Dadap dalam mengurasi konflik.

\section{3) Akomodasi}

Akomodasi merupakan suatu proses atau usaha untuk meredakan konflik agar mencapai suatu kestabilan. ${ }^{23}$ Akomodasi menunjukan pada sebuah keseimbangan dalam interaksi antara individu atau kelompok yang berhubungan dengan norma dan nilai sosial yang berlaku di masyarakat. Dalam pelaksanaan nadran masyarakat memiliki perbedaan pandangan, untuk mengurangi adanya suatu perbedaan atau pertentangan paada masyarakat yaitu dengan menyisipkan ajaran Islam kedalam suatu budaya. Mengenai hal ini, dalam perayaan nadran terdapat proses penyisipan, dimana nadran yang pada awalnya merupakan budaya yang begitu kental dengan Hindu-Budha

\footnotetext{
${ }^{22}$ J. W. M. Bakker. S. J. FILSAFAT KEBUDAYAAN Sebuah Pengantar, (Yogyakarta: PT KANISIUS, 1984), hlm: 115

${ }^{23}$ Dany Haryanto dan Edwi Nugrohadi, Pengantar Sosiologi Dasar, (Jakarta: PT Prestasi Pustakaraya), Hlm: 221
} 
namun seiring dengan berjalannya waktu, nadran disisipkan dengan budaya Islam, seperti tahlil, dan manaqiban.

\section{KESIMPULAN}

Masyarakat Desa Dadap dalam melaksanakan perayaan nadran memiliki cara tersendiri untuk menjauhkan hal-hal yang menimbulkan kemusyrikan. Masyarakat desa Dadap menyisipkan nilai-nilai ajaran agama Islam seperti tahlilan dan manaqiban. Tahlilan dan manaqiban merupakan kegiatan yang biasa dilakukan oleh masyarakat yang menganut agama Islam. Hal ini dilakukan untuk bertawashul kepada Nabi Khidir sebagai penjaga Laut agar tidak terjadi sesuatu yang tidak diinginkan ketika para nelayan melaut. Selain itu juga tahlilan dan manaqiban ini dilaksanakan untuk mengalap berkah.

Penjelasan diatas demikian, bisa dikatakan bahwa dalam mempertahankan tradisi lokal yaitu nadran pada masyarakat pesisir pantai utara ini sebenarnya terdapat proses negosiasi antara tradisi lokal dan tradisi Islam sehingga terjadi tarikmenarik agara saling menerima dan memberi melalui medan budaya yang mempertemukannya. Walaupun pada dasarnya hal ini menjadi konflik ideologi yang berkepanjangan. Namun tidak dengan perlawanan secara fisik masyarakat desa Dadap bersitegang dalam menanggapi perbedaan mengenai perayaan nadran. Masyarakat desa Dadap dengan menyisipkan ajaran-ajaran agama Islam bertujuan untuk untuk menghindari kemusyrikan dan juga menghindari konflik serta merangkul semuanya agar berjalan beriringan. Dengan demikian, dalam mengelola tradisi Islam dan tradisi lokal yaitu dengan menguburkan segala perbedaan serta mengedepankan persamaan-persamaan yang dapat mengurangi resiko konflik. Usaha-usaha untuk meredakan konflik ini melalui adanya asimilasi, akulturasi dan akomodasi.

\section{DAFTAR PUSTAKA}

Ali. Abdullah. 2007. Tradisi Kliwonan Gunung Jati Model Wisata Religi Kabupaten Cirebon. Yogyakarta: Cakrawala dan Pemerintah Kabupaten Cirebon.

Geertz. Clifford. 1989. The Religion of Java. diterj. Aswab Mahasin. Abangan, Santri, Priyayi dalam Masyarakat Jawa. Jakarta: Pustaka Jaya. 
1998. After The Fact: Two Countries, Four Decades, One Anthropologist. Diterj. Landung Simatupang. After The Fact: Dua Negeri, Empat Dasawarsa, Satu Antropolog. Yogyakarta: LkiS.

Haryanto, Dany dan Edwi Nugrohadi. 2011. Pengantar Sosial Dasar. Jakarta: PT Prestasi Pustakaraya.

J. W. M. Bakker. S. J. 1984. FILSAFAT KEBUDAYAAN Sebuah Pengantar. Yogyakarta: KANISIUS.

Kementrian Pendidikan dan Kebudayaan. Indonesia dalam Arus Sejarah 2: Kerajaan Hindu-Budha. PT. Ichtiar Baru Van Hoeve Kerjasama dengan Kementrian Pendidikan dan Kebudayaan Republik Indonesia

Kementerian Pendidikan dan Kebudayaan. Indonesia dalam Arus Sejarah 3:Kedatangan dan Peradaban Islam. PT. Ichtiar Baru Van Hoeve Kerjasama dengan Kementrian Pendidikan dan Kebudayaan Republik Indonesia

Kholil. Ahmad. 2001. Agama Kultural Masyarakat Pinggiran. Malang: UINMaliki Press

Moleong. Lexy J. 2013. Metode Penelitian Kualitatif. Bandung: PT Remaja Rosdakarya.

Thohir. Ajid. 2009. Studi Kawasan Dunia Islam. Jakarta: PT Rajagrafindo Persada.

Scharf. Betty R. 2004. The Sociological Study of Religion, diterjm: Machnun Husein, Sosiologi Agama. JakartaTimur: Prenada Media.

Robertson. Roland. 1993. Sosiology of Religion. terjmh: Ahmad Fedyani Saifuddin, AGAMA: dalam Analisa dan Interpretasi Sosiologis. Jakarta: PT Raja Grafindo Persada. 